MATEC Web of Conferences 24,07002 (2015)

DOI: $10.1051 /$ matecconf/ 20152407002

C Owned by the authors, published by EDP Sciences, 2015

\title{
Evaluation of human-induced vibration of continuous footbridges
}

\author{
Ahmed El-Robaa ${ }^{1, a}$, Sameh Gaawan ${ }^{2, b}$ and Charles Malek ${ }^{1, c}$ \\ ${ }^{1}$ Dar Al-Handasah Consultants, Structures Department, Street 26 Building 10 - Smart Village, Giza 12577, Egypt \\ ${ }^{2}$ Helwan University, Structures Department, Ibrahim Abdel Razeq Street, Cairo 11718, Egypt
}

\begin{abstract}
With the development of construction materials and the introduction of high strength steel and concrete, the human-induced vibration became a dominant criterion for the design of pedestrian bridges. Currently, longer spans and lightweight bridges have been comprised in most of design trends. This leads to lower the natural frequencies of the system which have a great effect on the dynamic performance of bridges subjected to human activities. Although the design of steel footbridges could reach the optimum level of design in terms of strength criterion, it might not reach the acceptance level for vibration condition. This will enforce the designer to choose section profiles with higher inertia to enhance stiffness of the whole system. This paper presents an overall assessment for floor vibration problem due to pedestrian induced vertical forces on continuous composite footbridges. The footfall method presented by concrete centre "CCIP-016" is adopted in this study to evaluate the response factor and acceleration of pedestrian bridges using a FEA software package "Robot Structural Analysis".
\end{abstract}

\section{Introduction}

Nowadays, high strength materials are widely used in order to achieve the most efficient and low cost design. This leads to long spans - lightweight structures. This methodology results in special serviceability checks that, more often than not, control the design; i.e., acceptable acceleration (vibration) limits. Vibration actions are induced by human walking forces on the slab; thus, human comfort needs to be deeply investigated as a controlling serviceability limit.

The traditional design approaches for serviceability was limited to checking deflection values due to live load against specified code values or limiting the span-todepth ratio as a more simplified approach. However, current design practice reveals that such design methods could not ensure acceptable levels for human comfort at all cases. The design guidelines for vibration serviceability of footbridges in the vertical direction depend on estimation of vibration response to single person walking at a pacing frequency that matches the natural frequency of the relevant vibration mode. Footbridges which exhibit vibration serviceability problems are mostly low-frequency flexible structures.

The magnitude of vertical loads induced by pedestrians on various types of structures has been quantified by many measurements. A walking person produces a vertical force that can be simulated as a continuous periodic function. This means that, since one foot is always in contact with the floor, there is no time where the load completely disappears.
The body weight is shifted from one foot to the other during the transition period of the motion sequence (Figure 1) and the two load curves for each foot overlap.

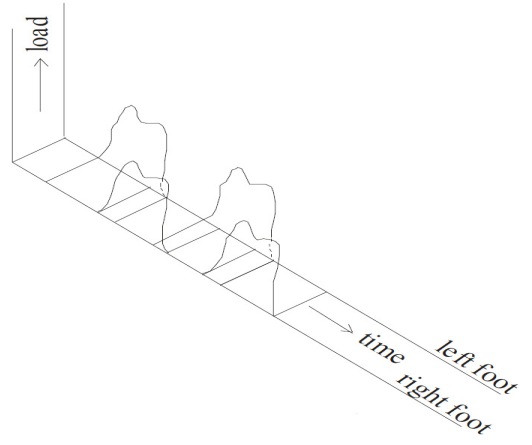

Figure 1. Illustration of human walking forces [1]

Psychological influences and individual characteristics have a significant effect on the human perception of vibrations [2]. This perception is influenced by the physical factors, vibration frequency, acceleration and the time period of exposure. The discomfort depends much on the environmental conditions and the attitude towards the vibration cause. One of the powerful design guides to assess vibration problem due to human induced forces is the one published by "The Concrete Centre" CCIP-016[3].

This design guide illustrates a rigorous analysis method for calculating structural response due to single walking person which is called footfall analysis method.

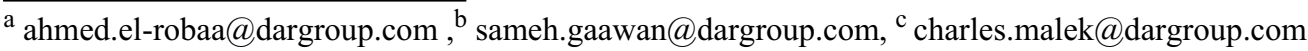


In this analysis, two different responses are calculated due to vertical human force; the resonant and the impulsive vibration responses. These types of response are associated with low or high frequency floors. Structures with fundamental vertical natural frequencies less than 4.2 times the fastest walking frequency shall be designed for resonant response.

In this analysis, a response factor (R) is calculated. This factor is a multiplier of the base line curve for RMS acceleration (vertical direction) according to BS 64721992[4]. This curve corresponds to the level of the average threshold of human perception in continuous vibration. A response factor of 1 represents the magnitude of vibration that is just perceptible by a typical human. The performance criteria given in [3] are applicable for bridges of all spans and natural frequencies. These criteria are given for indoor and outdoor bridges as follows:

a) For external bridges: $\mathrm{R}<64$.

b) For indoor bridges: $\mathrm{R}<32$.

c) For indoor bridges that are exposed, high in an atrium or heavily trafficked $\mathrm{R} \sim 24$.

CCIP method as illustrated above is used in this study, emphasizing on the effect of floor vibration on optimized steel bridges.

\section{Analysis and parameters}

This paper focuses on the study of the vertical vibration due to human induced forces on footbridges, where structural sections are optimized for both strength and deflection limit states.

The study is investigating the behaviour of continuous footbridge composed of three hinged supported composite steel beams with two equal spans. A reinforced concrete (R.C.) composite slab cast on metal decking is forming the bridge deck and supported on the two main beams. The total depth of the R.C. slab with the corrugation of the metal decking is $160 \mathrm{~mm}$ as shown in Figure 2. The bridge width is selected as $3.0 \mathrm{~m}$ which is a common value for typical footbridges. This continuous footbridge is analyzed for two equal spans ranging from $10 \mathrm{~m}$ to $50 \mathrm{~m}$ for each bay.

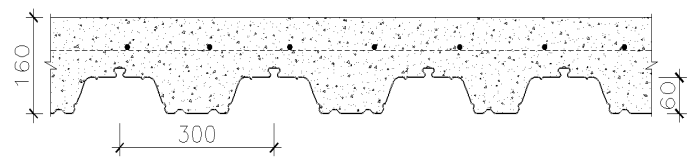

Figure 2. $160 \mathrm{~mm}$ thick R.C. composite slab on metal deck.

Each main beam consists of two parts: one of them is a prismatic cross-section for sagging zone, and the other one is haunched section for hogging zone. The analysis models are chosen with different finish and installation loadings. The total finishes and installation loads are considered as $100 \mathrm{Kg} / \mathrm{m}^{2}$ for low-finished bridges, 300 $\mathrm{Kg} / \mathrm{m}^{2}$ for average-finish types and $800 \mathrm{Kg} / \mathrm{m}^{2}$ for heavyfinish which is suited for footbridges in special locations such the Holy Haram at Makkah. The live load is considered as 90 psf as per AASHTO LRFD guide specifications for the design of pedestrian bridges [5].
High strength steel with yield strength of $345 \mathrm{MPa}$ is assumed in the design of the composite main girders. The concrete strength is considered as $30 \mathrm{MPa}$. These values of steel and concrete strength represent the most common values in the construction industry.

Thus, a total of fifteen footbridges were designed based on strength and deflection limit states. The optimized cross sections are obtained following the requirements of AISC 360-10[6] for design of composite members. The utilization ratio of steel main beams based on strength can be expressed by comparing the applied external moments against the cross sectional bending capacity. Hereafter, this ratio is referred to as strength unity check. Deflection due to live load is compared to a value of $(\operatorname{span} / 360)$, where the span is taken as the distance between zero moments at sagging zone. Deflection unity check is the ratio between the live load deflections to the value of ( $\mathrm{span} / 360)$. The required steel cross section for most of the studied cases was controlled by the strength limit state for hogging moments. However; for sagging moments, the cross sections are controlled by deflection limit state.

These strength or deflection optimized steel cross sections were checked for human comfort by footfall analysis. To compute the overall response factor of a structure, the following points illustrate the required steps in accordance with CCIP-016[3]:

1- First, a range of walking frequencies is chosen (typically 1 to $2.8 \mathrm{~Hz}$ ) to generate various number of step frequencies. Then, the forcing function is calculated for a selected step frequency in that chosen range.

2- Secondly, this forcing function is applied at chosen nodes in the structure, and the response at these nodes and at all the other nodes is then calculated. This is carried out for each of the four harmonic components of the forcing function with their corresponding harmonic frequencies.

3- Thirdly, based on the obtained accelerations, a total response factor is calculated from combination of each of the four harmonic responses for the selected step frequency.

4- Finally, these steps are repeated until the whole range of frequencies is covered, and the maximum response factor $\mathrm{R}$ is the value that sets the acceptance of a structure.

Robot Structural Analysis software [7] is used for footfall analysis. The concrete slab is simulated with orthotropic shell element of $160 \mathrm{~mm}$ total depth composed with a trapezoidal plate following the steel profile deck, its ribs are perpendicular to the main beams, and with an offset to account for the composite action as shown in Figure 3.

The dynamic modulus of elasticity for concrete is chosen as $38 \mathrm{kN} / \mathrm{mm}^{2}$. In order to consider the noncomposite properties at hogging zone, the modulus of elasticity for steel at this zone is reduced by the ratio between cross section inertia of steel only and composite inertia considering R.C. slab on top. The R.C. slab is simulated as 4-noded quadrilateral finite element with mesh size of $0.1 \mathrm{~m}$ by $0.1 \mathrm{~m}$. 
The walker weight is assumed as $76 \mathrm{~kg}$ and the damping ratio considered in the analysis is $1 \%$ for composite footbridges.
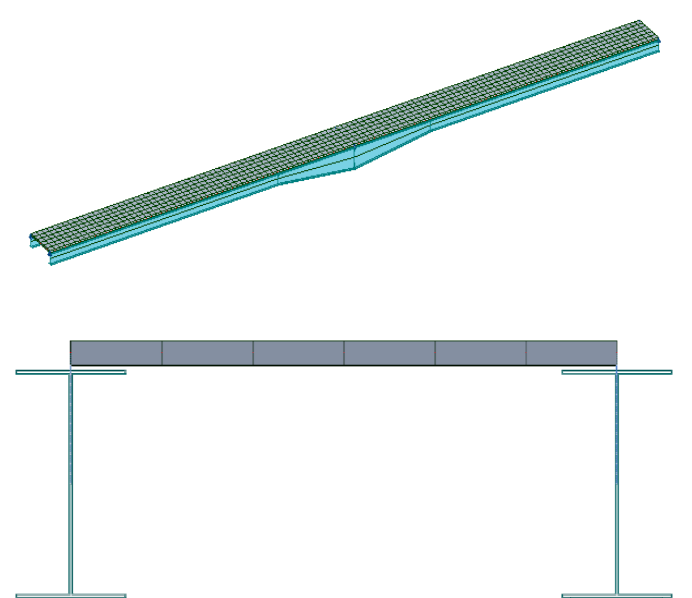

Figure 3. 3D FE analysis model and cross section of the bridge with offset in slab.

\section{Results discussion}

The optimized steel cross sections of the fifteen footbridges along with the strength and deflection unity checks and the overall response factors are shown in Table 1. The optimized steel cross sections are controlled by the deflection limit state at sagging zone for most profiles; however the cross sections at the hogging zone are optimised to the topmost level of strength. The overall response factor $(\mathrm{R})$ for all the optimized fifteen bridges resulted from all types of finishes are higher than human comfort level for heavily trafficked indoor bridges $(\mathrm{R}<24)$. If the studied footbridges are considered as external bridges $(R<64)$, only the case of heavy-finish can be considered satisfying the human comfort level as shown in Table 1. The overall response factor $(\mathrm{R})$ for the other two types of finishes (low and average) is not satisfying the human comfort level for external bridges for most of the cases. A sample for the contour distribution of the response as obtained from FE model is shown in Figure 4 for finish weight of $100 \mathrm{~kg} / \mathrm{m}^{2}$ and two equal spans of $30 \mathrm{~m}$ length for each bay.

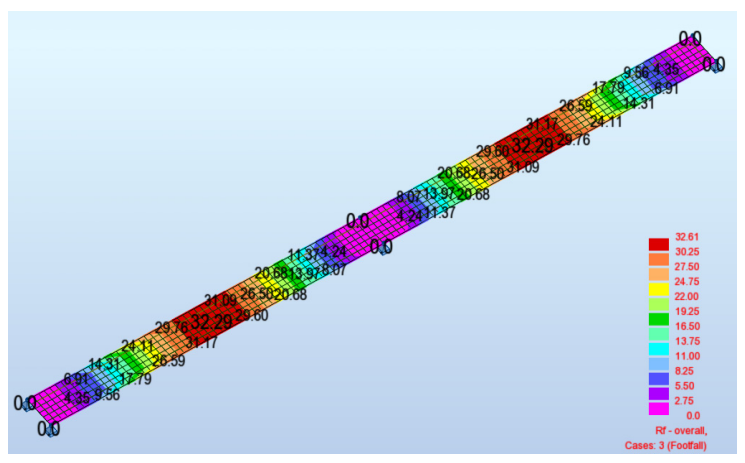

Figure 4. Overall response factor resulted from two equal spans of $30 \mathrm{~m}$ length footbridge with finish weight of 100 $\mathrm{kg} / \mathrm{m}^{2}$.
From Figure 4, it is inferred that the maximum vibration response is noticed at the mid-span of the footbridge. The fundamental vertical natural frequency for all footbridges is also listed in Table 1. Some international standards such as AASHTO [5] recommend that the fundamental frequency shall not be less than $3 \mathrm{~Hz}$ to achieve human comfort. However, for $10 \mathrm{~m}$ span and with low finishes, the frequency exceeds the $3 \mathrm{~Hz}$ limit; yet, the human comfort is still not attained. This is due to the fact that the method of footfall analysis used in CCIP016 [3] takes into account the first four harmonics of the human forcing function. And for the case of higher harmonics, the frequency of the walker sometimes coincides with the natural frequency of the footbridge, which would lead to higher response factors.

As discussed above, most of the optimized steel main beams have not satisfied the human comfort acceptance level for internal and external footbridges. Only the case of external footbridges with heavy finishes is found satisfactory. Accordingly, the cross section sizes were increased in order to attain the acceptable acceleration limits for indoor and outdoor bridges. Such increase in cross section sizes has an impact on the total self-weight of the bridge. Another round of footfall analysis has been performed to achieve two target levels, one to satisfy response factor less than 24 and another one for response factor of 64 . These targets are achieved by increasing the cross section properties more than the ones previously controlled by strength/deflection limits. The ratio of the new cross section to the optimized cross section weights is used to quantify the required increase in the beam dimensions to satisfy the human comfort levels, and is referred to hereunder as "weight increase ratio".

Figure 5 illustrates the weight increase ratio for different types of finishes in order to achieve a comfort level of $\mathrm{R}<24$. It is concluded from this figure that footbridges with heavy finishes $\left(800 \mathrm{~kg} / \mathrm{m}^{2}\right)$ require lesser increase in beam weight to achieve the acceptable comfort levels compared to light and average finishes. The maximum required increase is observed in light weight finishes $\left(100 \mathrm{~kg} / \mathrm{m}^{2}\right)$ and shorter spans. Since the comfort criterion of $\mathrm{R}<24$ is a very stringent one, the weight increase ratios reach 2.35 to 4.6 times the original weight. On the other hand, such ratio reaches only 1.26 times the original weight for large spans (40-50 m).

Figure 6 illustrates the weight increase ratio for different types of finishes in order to achieve a comfort level of $\mathrm{R}<64$. For this case, the required weight increase ratios are much smaller compared to the ones required for indoor bridges. It is also observed that, for footbridges with heavy finishes $\left(800 \mathrm{~kg} / \mathrm{m}^{2}\right)$, the comfort criterion is already obtained from the first round of optimization; consequently, the weight increase ratio is unity for all spans ranging from $10 \mathrm{~m}$ to $50 \mathrm{~m}$. The maximum weight increase ratio is observed for short spans with light or average finishes, where it reaches values ranging from 1.18 to 1.31 for $10 \mathrm{~m}$ span. However, for longer spans (20 to $50 \mathrm{~m}$ ), such increase is very minimal and its value is less than 1.06 .

The fundamental natural frequency is recalculated for the increased steel main beams for the case of $\mathrm{R}<24$ and $\mathrm{R}<64$ as shown in Table 2 . 
Table 1. Data results obtained for optimised cross-sections with different finish weights.

\begin{tabular}{|c|c|c|c|c|c|c|c|c|}
\hline \multicolumn{9}{|c|}{ Finish weight $=100 \mathrm{Kg} / \mathrm{m}^{2}$} \\
\hline \multirow{2}{*}{$\begin{array}{l}\text { Span } \\
(\mathrm{m})\end{array}$} & \multicolumn{2}{|c|}{ Optimized Section } & \multirow{2}{*}{ 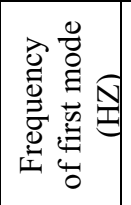 } & \multirow{2}{*}{$\begin{array}{l}\text { Strength } \\
\text { Unity } \\
\text { Check at } \\
\text { Hogging } \\
\text { Section }\end{array}$} & \multirow{2}{*}{ 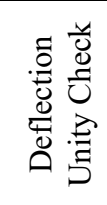 } & \multirow{2}{*}{$\begin{array}{l}\text { Overall } \\
\text { Response } \\
\text { Factor } \\
\text { (R) }\end{array}$} & \multirow{2}{*}{$\begin{array}{c}\text { External } \\
\text { Bridge } \\
\mathrm{R}<64\end{array}$} & \multirow{2}{*}{$\begin{array}{c}\text { Heavily } \\
\text { trafficked } \\
\text { Indoor } \\
\text { Bridge } \\
\mathrm{R}<24\end{array}$} \\
\hline & $\begin{array}{l}\text { Sagging } \\
\text { Section }\end{array}$ & $\begin{array}{l}\text { Hogging } \\
\text { Section }\end{array}$ & & & & & & \\
\hline 10 & $\begin{array}{c}250 \times 120 \mathrm{x} \\
5 \mathrm{x} 5\end{array}$ & $\begin{array}{c}500 \times 120 x \\
14 \times 5\end{array}$ & 3.01 & 1 & 0.98 & 81.69 & $\begin{array}{c}\text { non } \\
\text { comfort }\end{array}$ & $\begin{array}{c}\text { non } \\
\text { comfort }\end{array}$ \\
\hline 20 & $\begin{array}{c}500 \times 250 \mathrm{x} \\
12 \times 6 \\
\end{array}$ & $\begin{array}{c}1000 \times 250 \mathrm{x} \\
14 \mathrm{x} 8 \\
\end{array}$ & 2.39 & 0.97 & 0.97 & 85.41 & $\begin{array}{c}\text { non } \\
\text { comfort }\end{array}$ & $\begin{array}{c}\text { non } \\
\text { comfort }\end{array}$ \\
\hline 30 & $\begin{array}{c}750 \times 350 \mathrm{x} \\
16 \times 8 \\
\end{array}$ & $\begin{array}{c}1500 \times 350 x \\
16 \times 10 \\
\end{array}$ & 1.93 & 1 & 1 & 32.29 & comfort & $\begin{array}{c}\text { non } \\
\text { comfort }\end{array}$ \\
\hline 40 & $\begin{array}{c}1000 \times 500 \\
\times 16 \times 12\end{array}$ & $\begin{array}{c}2000 \times 500 x \\
16 \times 12\end{array}$ & 1.65 & 0.96 & 1 & 71.27 & $\begin{array}{c}\text { non } \\
\text { comfort }\end{array}$ & $\begin{array}{c}\text { non } \\
\text { comfort }\end{array}$ \\
\hline 50 & $\begin{array}{c}1250 \times 600 \\
\times 18 \times 14 \\
\end{array}$ & $\begin{array}{c}2500 \times 600 \mathrm{x} \\
18 \times 14 \\
\end{array}$ & 1.44 & 0.99 & 1 & 36.3 & comfort & $\begin{array}{c}\text { non } \\
\text { comfort }\end{array}$ \\
\hline \multicolumn{9}{|c|}{ Finish weight $=300 \mathrm{Kg} / \mathrm{m}^{2}$} \\
\hline \multirow{2}{*}{$\begin{array}{l}\text { Span } \\
(\mathrm{m})\end{array}$} & \multicolumn{2}{|c|}{ Optimized Section } & \multirow{2}{*}{ 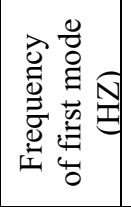 } & \multirow{2}{*}{$\begin{array}{l}\text { Strength } \\
\text { Unity } \\
\text { Check at } \\
\text { Hogging } \\
\text { Section }\end{array}$} & \multirow{2}{*}{ 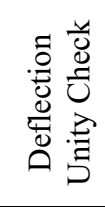 } & \multirow{2}{*}{$\begin{array}{l}\text { Overall } \\
\text { Response } \\
\text { Factor } \\
\text { (R) }\end{array}$} & \multirow{2}{*}{$\begin{array}{c}\text { External } \\
\text { Bridge } \\
\mathrm{R}<64\end{array}$} & \multirow{2}{*}{$\begin{array}{c}\text { Heavily } \\
\text { trafficked } \\
\text { Indoor } \\
\text { Bridge } \\
\mathrm{R}<24\end{array}$} \\
\hline & $\begin{array}{l}\text { Sagging } \\
\text { Section }\end{array}$ & $\begin{array}{l}\text { Hogging } \\
\text { Section }\end{array}$ & & & & & & \\
\hline 10 & $\begin{array}{c}250 \times 120 x \\
5 \times 5\end{array}$ & $\begin{array}{c}500 \times 120 x \\
18 \times 5\end{array}$ & 2.55 & 1 & 0.97 & 124.1 & $\begin{array}{c}\text { non } \\
\text { comfort }\end{array}$ & $\begin{array}{c}\text { non } \\
\text { comfort }\end{array}$ \\
\hline 20 & $\begin{array}{c}500 \times 250 x \\
12 \times 6\end{array}$ & $\begin{array}{c}1000 \times 250 \mathrm{x} \\
18 \mathrm{x} 8\end{array}$ & 2.02 & 1 & 0.95 & 41.66 & comfort & $\begin{array}{c}\text { non } \\
\text { comfort }\end{array}$ \\
\hline 30 & $\begin{array}{c}750 \times 350 x \\
16 \times 8\end{array}$ & $\begin{array}{c}1500 \times 350 \mathrm{x} \\
22 \times 10\end{array}$ & 1.66 & 1 & 0.98 & 47.65 & comfort & $\begin{array}{c}\text { non } \\
\text { comfort }\end{array}$ \\
\hline 40 & $\begin{array}{c}1000 \times 500 \\
\times 16 \times 12\end{array}$ & $\begin{array}{c}2000 \times 500 x \\
20 \times 12\end{array}$ & 1.43 & 1 & 0.99 & 67.46 & $\begin{array}{c}\text { non } \\
\text { comfort }\end{array}$ & $\begin{array}{c}\text { non } \\
\text { comfort }\end{array}$ \\
\hline 50 & $\begin{array}{c}1250 \times 600 \\
\times 18 \times 14\end{array}$ & $\begin{array}{l}2500 \times 600 \mathrm{x} \\
22 \times 15\end{array}$ & 1.26 & 1 & 1 & 24.7 & comfort & $\begin{array}{c}\text { non } \\
\text { comfort }\end{array}$ \\
\hline \multicolumn{9}{|c|}{ Finish weight $=800 \mathrm{Kg} / \mathrm{m}^{2}$} \\
\hline \multirow{2}{*}{$\begin{array}{l}\text { Span } \\
(\mathrm{m})\end{array}$} & \multicolumn{2}{|c|}{ Optimized Section } & \multirow{2}{*}{ 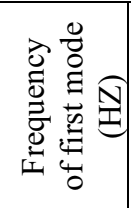 } & \multirow{2}{*}{$\begin{array}{l}\text { Strength } \\
\text { Unity } \\
\text { Check at } \\
\text { Hogging } \\
\text { Section }\end{array}$} & \multirow{2}{*}{ 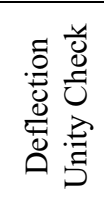 } & \multirow{2}{*}{$\begin{array}{l}\text { Overall } \\
\text { Response } \\
\text { Factor } \\
\text { (R) }\end{array}$} & \multirow{2}{*}{$\begin{array}{c}\text { External } \\
\text { Bridge } \\
\mathrm{R}<64\end{array}$} & \multirow{2}{*}{$\begin{array}{c}\text { Heavily } \\
\text { trafficked } \\
\text { Indoor } \\
\text { Bridge } \\
\mathrm{R}<24\end{array}$} \\
\hline & $\begin{array}{l}\text { Sagging } \\
\text { Section }\end{array}$ & $\begin{array}{l}\text { Hogging } \\
\text { Section }\end{array}$ & & & & & & \\
\hline 10 & $\begin{array}{c}250 \times 120 x \\
8 \times 5\end{array}$ & $\begin{array}{c}500 \times 120 x \\
30 x 6\end{array}$ & 2.17 & 0.97 & 0.765 & 56.9 & comfort & $\begin{array}{c}\text { non } \\
\text { comfort }\end{array}$ \\
\hline 20 & $\begin{array}{c}500 \times 250 \mathrm{x} \\
12 \mathrm{x} 6\end{array}$ & $\begin{array}{c}1000 \times 250 \mathrm{x} \\
30 \times 10\end{array}$ & 1.55 & 1 & 0.92 & 42.98 & comfort & $\begin{array}{c}\text { non } \\
\text { comfort }\end{array}$ \\
\hline 30 & $\begin{array}{c}750 \times 350 x \\
16 x 8\end{array}$ & $\begin{array}{c}1500 \times 350 x \\
35 \times 12\end{array}$ & 1.29 & 1 & 0.95 & 53.46 & comfort & $\begin{array}{c}\text { non } \\
\text { comfort }\end{array}$ \\
\hline 40 & $\begin{array}{c}1000 \times 500 \\
\times 16 \times 12\end{array}$ & $\begin{array}{c}2000 \times 500 x \\
35 \times 14\end{array}$ & 1.14 & 0.97 & 0.96 & 30.48 & comfort & $\begin{array}{c}\text { non } \\
\text { comfort }\end{array}$ \\
\hline 50 & $\begin{array}{c}1250 \times 600 \\
\times 18 \times 14\end{array}$ & $\begin{array}{c}2500 \times 600 \mathrm{x} \\
40 \mathrm{x} 16\end{array}$ & 1.02 & 1 & 0.97 & 35.07 & comfort & $\begin{array}{c}\text { non } \\
\text { comfort }\end{array}$ \\
\hline
\end{tabular}




\section{EVACES'15}

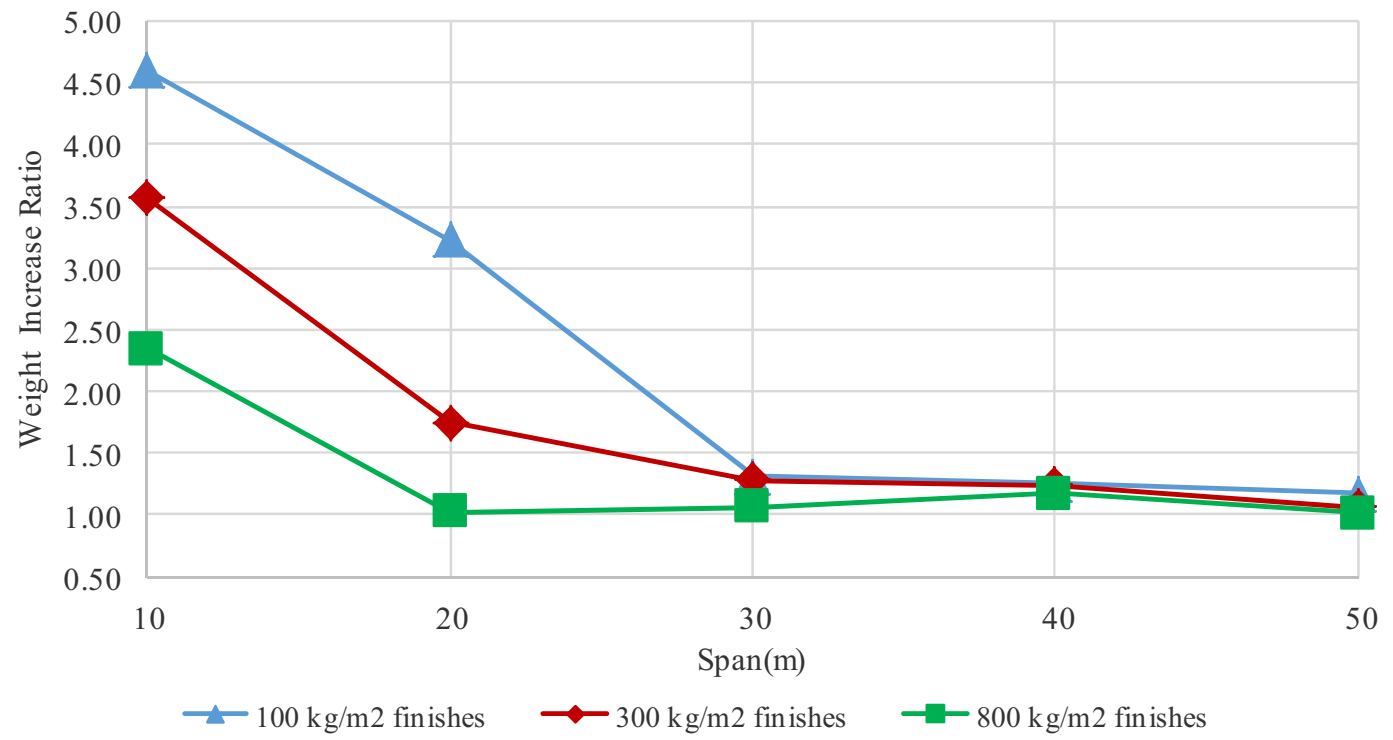

Figure 5. The weight increase ratio to satisfy an overall response factor of $\mathrm{R}<24$ for heavily trafficked indoor bridges.

It is worth mentioning that, although the natural frequency of some footbridges shown on Table 2 is less than $3 \mathrm{~Hz}$, the human comfort is satisfied. Thus, it can be concluded that it is not practical to impose certain single value limit on fundamental natural frequency to achieve human comfort. Generally, if a limit on the natural frequency is to be thought of, such limit must be related mainly to the span of the footbridge. The limit on natural frequency shall be set higher for shorter spans and decreased with the increase of the footbridge span. A wider range of spans, loading, and widths of footbridge need to be further investigated to reach a generalized limit of the fundamental natural frequency for footbridges.

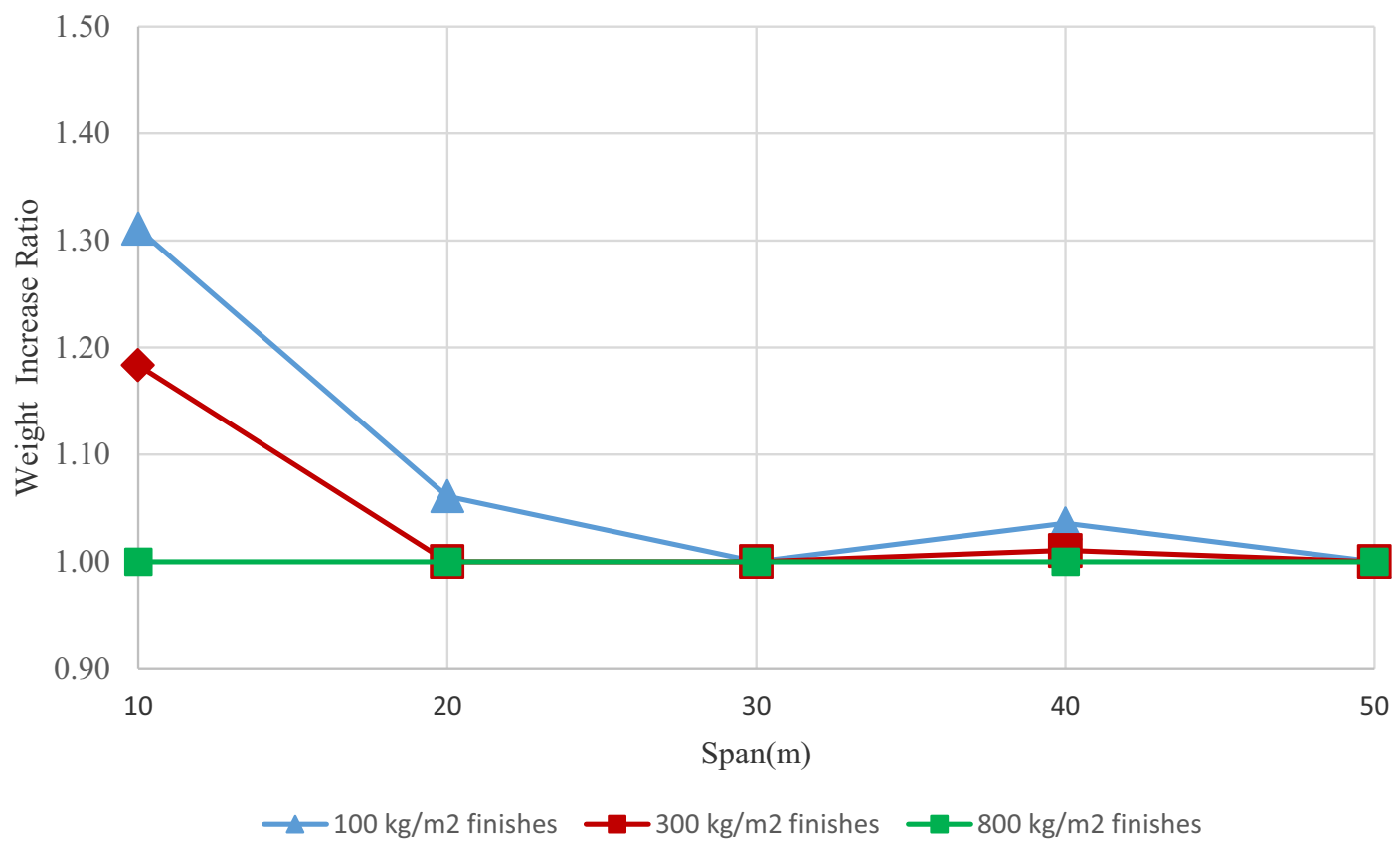

Figure 6. The weight increase ratio to satisfy an overall response factor of $\mathrm{R}<64$ for external bridges. 
Table 2 Frequency results to reach the required limits for indoor and external bridge.

\begin{tabular}{|c|c|c|c|c|c|}
\hline \multicolumn{6}{|c|}{ Frequency $(\mathrm{Hz})$ if $\mathrm{R}<24$ is reached } \\
\hline \multirow{2}{*}{$\begin{array}{c}\text { Finish } \\
\text { weight } \\
\left(\mathrm{Kg} / \mathrm{m}^{2}\right)\end{array}$} & \multicolumn{5}{|c|}{$\operatorname{Span}(\mathrm{m})$} \\
\hline & 10 & 20 & 30 & 40 & 50 \\
\hline 100 & 11.25 & 5.42 & 3.81 & 2.03 & 2.11 \\
\hline 300 & 7.60 & 3.96 & 1.95 & 1.89 & 1.30 \\
\hline 800 & 4.80 & 1.69 & 1.62 & 1.8 & 1.03 \\
\hline \multicolumn{6}{|c|}{ Frequency (Hz) if $\mathrm{R}<64$ is reached } \\
\hline \multirow{2}{*}{$\begin{array}{c}\text { Finish } \\
\text { weight } \\
\left(\mathrm{Kg} / \mathrm{m}^{2}\right)\end{array}$} & \multicolumn{5}{|c|}{ Span $(\mathrm{m})$} \\
\hline & 10 & 20 & 30 & 40 & 50 \\
\hline 100 & 4.75 & 2.86 & 1.93 & 1.81 & 1.44 \\
\hline 300 & 3.74 & 2.02 & 1.66 & 1.47 & 1.26 \\
\hline 800 & 2.17 & 1.55 & 1.29 & 1.14 & 1.02 \\
\hline
\end{tabular}

\section{Conclusion}

The current study highlights the impact of satisfying human comfort levels on the optimized composite steel footbridges. The following can be concluded from the above tables and figures:

1- The effect of applied finish weights on human comfort has a big influence on the design of footbridges. Thus, the required design alterations to reach acceptable vibration limits for a bridge loaded with a relatively heavy weight of finishes $\left(800 \mathrm{Kg} / \mathrm{m}^{2}\right)$ are less than those required for bridges with lighter weight finishes $\left(100 \mathrm{Kg} / \mathrm{m}^{2}\right)$. In addition to that, heavily trafficked indoor bridges need more design refinements than those required for external bridges to overcome vibration problems.

2- The human comfort level of $\mathrm{R}<24$ is very stringent, and substantial increase in the cross section dimensions of main girders might be required to satisfy such strict limit. It is easier and much less costly to achieve human comfort level of $\mathrm{R}<64$ as imposed by codes for external bridges.

3- Despite the fact that the natural frequency for some longer spans $(40$ to $50 \mathrm{~m}$ ) is less than $3 \mathrm{~Hz}$, the human comfort is achieved according to the recommended limits of CCIP-016[3] for both indoor and outdoor footbridges. On the other hand, for some footbridges which have a frequency of almost $3 \mathrm{~Hz}$, human comfort is not achieved.

4- Any limit on fundamental natural frequency must be inversely proportional to the bridge span. The longer the span is, the lower required limit of natural frequency.

5- It is important to emphasize that the vibration constraint should not be controlled by $3 \mathrm{~Hz}$ criterion as recommended by AISC design guide no. 11 [8] or AASHTO LRFD guide for pedestrian bridges [5]. Instead, dynamic footfall analysis shall be performed to take into account the full range of walking frequencies and the first four harmonics of the walker's forcing function. The latter leads to more accurate assessment of vibration of floors due to human induced forces.

\section{References}

1. S. Živanović, A. Pavić, P. Reynolds, J. Sound \& Vib. 279,1-74, (2005)

2. M. Schlaich, J. Francois, Guidelines for design of footbridges, (FIB Bulletin 32, 2005)

3. M. Willford and P.Young, A design guide for footfall induced vibration of structures (CCIP-016, 2006)

4. British standard institution, Guide to evaluation of human exposure to vibration in buildings (1 Hz to $80 \mathrm{~Hz}),(\mathrm{BS} 6472,1992)$

5. AASHTO, LRFD guide specifications for design of pedestrian bridges, (2009).

6. AISC, Specification for structural steel buildings, (AISC 360-10, 2010).

7. Autodesk, Autodesk Robot Structural Analysis Professional, (2015).

8. T.Murray, D. Allen and E. Ungar, Floor vibration due to human activity, (AISC, 2003). 